\title{
The Effect of Lockdown on the Mental and Physical Health of Romanian Medical Undergraduates
}

\author{
Octavian Ilarian BAIU', Monica DUGAESESCU², Teodor-Cristian BLIDARU²
}

\begin{abstract}
As a response to the COVID-19 pandemic, medical universities were closed in Romania, between March 2020 and July 2020. The educational process was transferred to an on-line environment, in person contact becoming nonexistent outside the group of people from one's household. The purpose of this study is to provide an overview of the mental health status in medical undergraduates in Romania during lockdown.

A questionnaire was used in April 2020 to collect information regarding the life of students during social isolations and to assess the mental health of students using a self-reported 1-7 scale on 21 relevant endpoints. After data quality control, the remaining 1978 data entries were analysed in SPSS 20.

We identified multiple factors that may contribute to the mental health of undergraduate students, such as: partner status and offline contact, personality traits, social media and streaming platforms usage. There were differences regarding the mental health status indicated by endpoints between: genders, living environment, owning a pet, etc. This study describes how mental health, a neglected subject in the Romanian public health arena, is influenced by various factors during lockdowns. Further research should be conducted and appropriate measures should be taken to prevent the degradation of mental health in medical students under pandemic circumstances.
\end{abstract}

Keywords: lockdown, Romania, medical undergraduates, mental health, social isolation, intimate relationship, social media, streaming platform.

\section{Rezumat}

Ca răspuns la pandemia COVID-19, universitățile cu profil medical din România au fost închise în perioada martie 2020-iulie 2020. Procesul educațional a fost transferat în mediul online, interacțiunile fizice devenind inexistente în afara grupului de persoane din gospodărie. Scopul acestui studiu este de a oferi o imagine de ansamblu asupra stării de sănătate mintală a studenților mediciniști din România în timpul stării de urgență.

Un chestionar a fost distribuit în aprilie 2020 pentru a colecta informații cu privire la sănătatea mintală a studenților în timpul izolării, utilizând o scară 1-7 pe 21 de criterii relevante autoraportate. Cele 1978 de răspunsuri obținute au fost analizate în SPSS 20.

Am identificat mai mulți factori care pot contribui la un prognostic bun pentru sănătatea mintală a studenților, cum ar fi: prezența unui partener intim, trăsăturile de personalitate, utilizarea social media și a platformelor de streaming. Au existat diferențe în ceea ce privește starea de sănătate mintală indicată de criteriile finale între: sexe, mediul de viață, deținerea unui animal de companie etc.

Acest studiu descrie cum sănătatea mintală, o problemă neglijată a sănătății publice din România, este influențată de diverși factori în timpul izolării. Sunt necesare cercetări suplimentare și măsuri adecvate pentru a preveni degradarea sănătății mintale în rândul studenților la medicină în condiții de pandemie.

Cuvinte cheie: stare de urgență, România, studenți la medicină, sănătate mintală, izolare socială, relații personale, social media, platforme de streaming.

\footnotetext{
${ }^{1}$ "Iuliu Hatieganu" University of Medicine and Pharmacy, ClujNapoca, Romania

2 "Carol Davila" University of Medicine and Pharmacy, Bucharest, Romania
}

Corresponding author.

Teodor Cristian BLIDARU, "Carol Davila" University of Medicine and Pharmacy, Bucharest, Romania.

E-mail: teodorblidaru@gmail.com 


\section{INTRODUCTION}

On the $11^{\text {th }}$ of March 2020, the World Health Organization recognised COVID-19 as a pandemic. This resulted in a series of measures designed to reduce the spread of the disease. Travel restrictions and social distancing were enforced.

As a response to the increasing cases of COVID-19, Romania declared lockdown, personal mobility being reduced to essential trips only. Another measure that was implemented with the purpose of reducing transmission was the closure of schools and universities, as this has been proven to have an effect on the amount of students infected ${ }^{1}$. Businesses and education were transferred to an online environment, in person contact becoming virtually nonexistent outside the group of people with whom one shared their home. While this resulted in a decrease in transmission, the lockdown might have had unintended consequences. As our activity turned to the internet, so did our social networks.

Though the current literature provides us with information about the psychological effects of an infectious viral outbreak ${ }^{2}$ there is no information on the effect of prolonged lockdown during a pandemic. While the effects of perceived social isolation ${ }^{3-5}$ and the association between social media usage and loneliness6 have been known for some time, the information is lacking on how these factors interweave in the context of an enforced lockdown. There is also insufficient information available regarding the effect of streaming services on mental wellbeing.

The purpose of this article is to provide an overview of the mental health situation in medical undergraduates in Romania and to uncover certain behaviors that have a positive influence on mental health during prolonged isolation periods.

\section{EXPERIMENTAL (MATERIALS AND METHODS)}

Our survey was carried out during the month of April 2020, one month after lockdown measures had been initiated in Romania. The study was conducted with the use of the Google Forms platform, and was distributed through the Facebook groups of medical students from across Romania with the help of the Romanian Federation of Medical Students' Association. The study aimed to assess the medical students' response to social isolation, to identify behaviors that had a positive effect on the mental health of the undergraduates and to provide recommendations should a situation that requires lockdown emerge again.
The first part of the questionnaire consisted of questions regarding the university center, year of study, gender, the living environment after lockdown, the number of people/household, information on pet ownership and opinion on its effect on mental health, the use of social media and streaming platforms and partner's status during pandemic. All the above-mentioned questions had a pre-established list of possible answers, and the responders selected the option corresponding to their situation.

Personality traits, such as openness and optimism, were also evaluated using a scale from 1 to 7 . For openness, a lower score is corresponding to introversion, while a higher score reflects extroversion. The scale for optimism used lower scores for pessimist responders, and higher scores for the optimists. The inclusion in one of these categories was based on self-evaluation of openness and optimism.

The last 21 questions were representing the endpoints regarding the mental health of medical students. Each one of them consisted of an affirmation associated with a scale from 1 to 7,1 corresponding to the lowest agreement (disagreement) and 7 to the highest agreement. The responders selected the score that reflects a subjective evaluation of their mental health status. Each affirmation was corresponding to one of the endpoints, whose abbreviation and descriptive statistics can be found in Table 1 .

\section{Table 1. Endpoints Descriptive Statistics}

\begin{tabular}{|l|c|c|}
\hline Endpoint & Mean & SD \\
\hline Understanding & 6.59 & 1.16 \\
\hline Interaction & 4.26 & 2.14 \\
\hline Stimulation & 4.1 & 1.95 \\
\hline Loneliness & 4.02 & 2.02 \\
\hline Frustration & 4.99 & 1.94 \\
\hline Anger & 4.98 & 1.95 \\
\hline Depression & 2.91 & 2.02 \\
\hline Purposelessness & 2.73 & 2 \\
\hline Time Unmanagement & 4.6 & 2.08 \\
\hline Time Wasting & 4.56 & 2.04 \\
\hline Overeating & 4.14 & 2.24 \\
\hline Concentration Problems & 4.6 & 2.12 \\
\hline Stress & 4.7 & 1.99 \\
\hline Virophobia & 3.72 & 1.94 \\
\hline Sedentarism & 4.82 & 2.15 \\
\hline Sleep Problems & 4.63 & 2.3 \\
\hline Distractions & 3.81 & 1.92 \\
\hline Energy & 3.24 & 1.75 \\
\hline Self Determination & 3.79 & 1.88 \\
\hline Activity & 4.88 & 1.76 \\
\hline Friends & 4.94 & 1.91 \\
\hline
\end{tabular}


A detailed model of the questionnaire is provided in Appendix A. Given that the method of collecting questionnaires could not attest for the identity of the person completing, a couple of methods were put in place to prevent maliciousness. Using the option provided by the platform, the questionnaire limited responses to one per IP. Obvious malevolent responders had been eliminated based on their answers on the open ended questions. This removed 9 answers from the total 1987.

The remaining 1978 data entries were analysed in IBM SPSS Statistics 20. All of the endpoints (scale variables), except for Understanding, followed normal distribution. A $\mathrm{T}$ test has been employed to verify the existence of an association between two groups (defined by the answers to categorical questions) for the endpoints that presented normal distribution. The endpoints that did not follow normal distribution were analysed with the Mann Whitney test. For those variables showing significance, the $\mathrm{p}$ value and the Mean Difference (MD) has been reported. For the scale questions (number 13-33) a cut-off of 0.3 (amounting to $5 \%$ of the possible range) has been chosen as the level of significance for the Mean Difference (MD). MDs of more than 0.25 have been mentioned as tendencies.

The effects of Openness and Optimism on the endpoints, and the effect of different endpoints on each other have been analysed with a linear regression. Only correlations with an $\mathrm{R}^{\wedge} 2$ of at least 0.05 have been included.

\section{RESULTS AND DISCUSSIONS}

The distribution of the 1978 responders by study year was as follows: $1^{\text {st }}$ year 591 responses, $2^{\text {nd }}$ year 450 responses, $3^{\text {rd }}$ year 383 responses, $4^{\text {th }}$ year 259 responses, $5^{\text {th }}$ year 208 responses, 6th year 87 responses. Out of the approximately 24000 medical students in Romania, this represents a response rate of 8\%. Out of the 1978 responders, 1572 identified as female, 389 as male and 16 preferred not to answer.

1686 of our responders were located in their parents' homes during the isolation, 281 were located in their own home or in a rented one, and 11 were housed in student dorms. 271 undergraduates affirmed that they were spending isolation with their romantic partner (CoLocked), 961 were spending it away from their partner (SoLocked) and 746 affirmed not having a romantic partner (Single).

The mean number of people in a household was 3.34 ( $\mathrm{SD}=1.189)$. People who have reported spending their lockdown with family reported a lower level of Sedentarism ( $\mathrm{p}=0.005, \mathrm{MD}=0.37)$, a higher level of Anger ( $\mathrm{p}=0.01, \mathrm{MD} 0.30)$ and a tendency towards higher Depression scores $(\mathrm{p}=0.03, \mathrm{MD}=0.29)$. There was a significant difference in the number of people in the household $(\mathrm{p}<0.0001)$ when comparing people locked in with their family (Mean=3.58) and people living in their own home (Mean=1.94). The number of people in the household had no effect on any of the endpoints ( $p>0.05$ for all 21 variables).

The majority of responders (65.1\%) reported increased Social Media Usage during the lockdown (SMU), compared to $29.7 \%$ who have not modified their usage, and $5.2 \%$ who have decreased their SMU. The same pattern remains constant for Streaming Platform Usage during the lockdown (SPU), the percentages being $64.8 \%, 30.4 \%$ and $4.7 \%$ respectively.

Women have reported a higher score on Purposelessness ( $\mathrm{p}=0.0001, \mathrm{MD}=0.41)$, TimeUnmanagement $(\mathrm{p}=0.018, \mathrm{MD}=0.37)$, ConcentrationProblems $(\mathrm{p}<0.0001, \mathrm{MD}=0.70)$, Stress $(\mathrm{p}<0.0001, \mathrm{MD} 0.66)$ and Virophobia $(\mathrm{p}<0.0001, \mathrm{MD}=0.62)$, and lower scores on Energy $(\mathrm{p}<0.0001, \mathrm{MD}=0.48)$, SelfDetermination $(\mathrm{p}<0.0001, \mathrm{MD}=0.62)$ and Distractions $(\mathrm{p}<0.0001$, $\mathrm{MD}=0.45)$ when compared to men.

1022 responders confirmed having a pet in their household. We have found no statistically significant difference between people who have a pet in their household and those who don't on any of the endpoints. 1668 responders believed that a pet would make the isolation experience more manageable. There was a highly significant difference regarding the opinion on the influence of pets between the responders who owned a

Table 2. Optimism ccorrelations

\begin{tabular}{|l|l|l|l|l|l|l|l|l|}
\hline & Loneliness & Depression & Purposelessness & $\begin{array}{l}\text { Concentration } \\
\text { Problems }\end{array}$ & Stress & Energy & $\begin{array}{l}\text { Self } \\
\text { Determination }\end{array}$ & Activity \\
\hline R & 0.238 & 0.321 & 0.256 & 0.225 & 0.258 & 0.310 & 0.316 & 0.224 \\
\hline R Square & 0.057 & 0.103 & 0.066 & 0.051 & 0.067 & 0.096 & 0.100 & 0.050 \\
\hline P & $<0.0001$ & $<0.0001$ & $<0.0001$ & $<0.0001$ & $<0.0001$ & $<0.0001$ & $<0.0001$ & $<0.0001$ \\
\hline B & -0.339 & -0.447 & -0.352 & -0.328 & -0.354 & 0.375 & 0.410 & 0.271 \\
\hline Constant & 5.567 & 4.942 & 4.332 & 6.097 & 6.316 & 1.535 & 1.922 & 3.646 \\
\hline
\end{tabular}


pet and those who did not $(\mathrm{p}<0.0001)$. As expected, the majority of 'No' responders to this question were those who did not own a pet.

People who have reported that they believe a pet to be useful in making their lockdown experience more manageable have reported higher scores on Overeating $\quad(\mathrm{p}=0.03, \mathrm{MD}=0.30)$, ConcentrationProblems ( $\mathrm{p}=0.009, \mathrm{MD}=0.34)$, Stress $(\mathrm{p}<0.0001$, $\mathrm{MD}=0.63)$, Virophobia ( $\mathrm{p}=0.0007, \mathrm{MD}=0.40)$, Depression $(\mathrm{p}=0.0003, \mathrm{MD}=0.45)$, Frustration $(\mathrm{p}<0.0001$, $\mathrm{MD}=0.51)$, Anger $(\mathrm{p}=0.0017, \mathrm{MD}=0.40)$, Loneliness $(\mathrm{p}=0.0003, \mathrm{MD}=0.46)$ and TimeWasting $(\mathrm{p}=0.018$, $\mathrm{MD}=0.30)$ and lower scores on Distractions $(\mathrm{p}=0.0013$, $\mathrm{MD}=0.40)$. There is also a tendency towards higher scores on TimeUnmanagement $(\mathrm{p}=0.042, \mathrm{MD}=0.27)$ and towards lower scores on SelfDetermination $(\mathrm{p}=0.028$, $\mathrm{MD}=0.26)$ and Energy $(\mathrm{p}=0.012, \mathrm{MD}=0.27)$.

CoLocked undergraduates reported lower scores on Anger $(\mathrm{p}=0.0006, \mathrm{MD}=0.47)$, Frustration $(\mathrm{p}=0.0003$, $\mathrm{MD}=0.47)$ and Loneliness $(\mathrm{p}<0.0001, \mathrm{MD}=1.37)$ and higher scores on Interaction ( $\mathrm{p}=0.0002, \mathrm{MD}=0.54)$ as compared to their SoLocked counterparts. They also reported a tendency towards lower SleepProblems score $(\mathrm{p}=0.09, \mathrm{MD}=0.26)$.
CoLocked undergraduates reported lower scores on Loneliness $(\mathrm{p}<0.0001, \mathrm{MD}=1.21)$ and higher scores on Friends $(p=0.031, M D=0.30)$, Sedentarism $(p=0.010$, $\mathrm{MD}=0.38)$ and Interactions $(\mathrm{p}=0.023, \mathrm{MD}=0.34)$ when compared to the Single undergraduates.

SoLocked undergraduates reported higher scores on Stress $(\mathrm{p}=0.0002, \mathrm{MD}=0.35)$, Anger $(\mathrm{p}=0.0001$, $\mathrm{MD}=0.37)$ and Frustration $(\mathrm{p}=0.0001, \mathrm{MD}=0.36)$ and lower scores on Distractions $(\mathrm{p}<0.0001, \mathrm{MD}=0.39)$ when compared to their Single counterparts. A tendency towards SleepProblems ( $\mathrm{p}=0.012, \mathrm{MD}=0.29)$ was also observed.

While the psychological or physical effects of extended periods of isolation have been studied on populations such as prison inmates housed in solitary housing units ${ }^{7}$, on ground spaceflight simulations ${ }^{8,9}$ and Antarctic research facilities ${ }^{10}$, the data is lacking on how a prolonged isolation period affects the population at large. Our study aims to provide an overview of the psychological effects of prolonged lockdown and to serve as a reference point for health policy decision makers.

Social isolation can be defined either as social isolation per se (the lack of social relationships) and percei-

Table 3. SMU and SPU differences. $*=p<0.05, * *=P<0.0001$

\begin{tabular}{|c|c|c|c|c|c|c|}
\hline Endpoint & $\begin{array}{l}\text { High vs Low } \\
\text { SMU }\end{array}$ & \begin{tabular}{|l|} 
High vs \\
unchanged \\
SMU
\end{tabular} & $\begin{array}{l}\text { Low vs } \\
\text { unchanged } \\
\text { SMU }\end{array}$ & $\begin{array}{l}\text { High vs Low } \\
\text { SPU }\end{array}$ & $\begin{array}{l}\text { High vs } \\
\text { unchanged SPU }\end{array}$ & $\begin{array}{l}\text { Low vs } \\
\text { unchanged SPU }\end{array}$ \\
\hline Understanding & 0.2 & 0.09 & -0.11 & 0.31 & 0.11 & -0.2 \\
\hline Interaction & -0.08 & 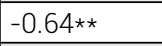 & $-0.56 *$ & -0.39 & -0.15 & 0.25 \\
\hline Stimulation & -0.12 & $-0.83 * \star$ & $-0.71 *$ & $-0.59 *$ & $-0.49 * \star$ & 0.1 \\
\hline Loneliness & $0.87 *$ & $0.94 \star \star$ & 0.08 & 0.46 & $0.50 * \star$ & 0.05 \\
\hline Frustration & $0.64 *$ & $0.96 * *$ & 0.32 & $0.77 *$ & $0.42 * *$ & -0.35 \\
\hline Anger & $0.83 *$ & $0.90 * \star$ & 0.07 & $0.70 *$ & $0.43 \star \star$ & -0.26 \\
\hline Depression & 0.01 & $0.66 * *$ & $0.69 *$ & $0.56 *$ & $0.21 *$ & -0.34 \\
\hline Purposelessness & 0.03 & $0.73 * \star$ & $0.66 *$ & $0.52 *$ & $0.34 *$ & -0.18 \\
\hline TimeUnmanagement & $0.78 *$ & $1.04 * *$ & 0.26 & $0.88 *$ & $0.46 * *$ & -0.42 \\
\hline TimeWasting & $0.96 * *$ & $1.12 \star \star$ & 0.15 & $1.26 * *$ & $0.60 * *$ & $-0.66 *$ \\
\hline Overeating & $0.54 *$ & $0.85 * *$ & 0.31 & $0.82 *$ & $0.87 \star *$ & 0.04 \\
\hline ConcentrationProblems & $0.67 *$ & $1.08 * *$ & 0.4 & $0.88 * *$ & $0.56 * *$ & -0.32 \\
\hline Stress & $0.51 *$ & $0.98 * *$ & 0.47 & $0.66 *$ & $0.37 *$ & -0.29 \\
\hline Virophobia & $0.48 *$ & $0.46 * *$ & -0.02 & 0.4 & $0.25 *$ & -0.15 \\
\hline Sedentarism & $0.46 *$ & $0.82 * \star$ & 0.36 & $0.89 * *$ & $0.68 * *$ & -0.2 \\
\hline SleepProblems & $0.65 *$ & $1.18 * *$ & $0.53 *$ & $0.73 *$ & $0.90 * *$ & 0.16 \\
\hline Distractions & $-0.85 * *$ & $-0.88 * *$ & -0.03 & $-1.22 \star \star$ & $-0.69 * *$ & $0.53 *$ \\
\hline Energy & $-0.51 *$ & $-0.78 * *$ & -0.28 & $-0.75 *$ & $-0.41 * *$ & 0.33 \\
\hline SelfDetermination & $-0.65 *$ & $-0.78 * *$ & -0.13 & $-0.66 *$ & $-0.40 * *$ & 0.26 \\
\hline Activity & -0.23 & $-0.42 \star \star *$ & -0.18 & $-0.51 *$ & $-0.30 *$ & 0.22 \\
\hline Friends & -0.03 & $-0.43 * *$ & -0.39 & 0.15 & -0.18 & -0.33 \\
\hline
\end{tabular}


The Effect of Lockdown on the Mental and Physical Health of Romanian Medical Undergraduates

Table 4. Loneliness correlations

\begin{tabular}{|l|l|l|l|l|l|}
\hline & R & R Square & P & B & Constant \\
\hline Interactions & 0.234 & 0.055 & $>0.0001$ & -0.242 & 5.234 \\
\hline Stimulation & 0.298 & 0.089 & $>0.0001$ & -0.280 & 5.229 \\
\hline Frustration & 0.520 & 0.270 & $>0.0001$ & 0.488 & 3.028 \\
\hline Anger & 0.466 & 0.217 & $>0.0001$ & 0.439 & 3.216 \\
\hline Depression & 0.493 & 0.243 & $>0.0001$ & 0.481 & 0.972 \\
\hline Purposelessness & 0.430 & 0.185 & $>0.0001$ & 0.415 & 1.060 \\
\hline TimeUnmanagement & 0.330 & 0.109 & $>0.0001$ & 0.331 & 3.268 \\
\hline TimeWasting & 0.343 & 0.118 & $>0.0001$ & 0.339 & 3.201 \\
\hline Overeating & 0.234 & 0.055 & $>0.0001$ & 0.253 & 3.122 \\
\hline ConcentrationProblems & 0.359 & 0.129 & $>0.0001$ & 0.368 & 3.126 \\
\hline Stress & 0.412 & 0.169 & $>0.0001$ & 0.396 & 3.112 \\
\hline Sedentarism & 0.239 & 0.057 & $>0.0001$ & 0.248 & 3.821 \\
\hline SleepProblems & 0.283 & 0.080 & $>0.0001$ & 0.315 & 3.363 \\
\hline Distractions & 0.294 & 0.086 & $>0.0001$ & -0.272 & 4.903 \\
\hline Energy & 0.327 & 0.107 & $>0.0001$ & -0.277 & 4.355 \\
\hline SelfDetermination & 0.321 & 0.103 & $>0.0001$ & -0.292 & 4.967 \\
\hline Friends & 0.299 & 0.090 & $>0.0001$ & -0.277 & 6.053 \\
\hline
\end{tabular}

ved social isolation (the feeling of lacking meaningful relationships) ${ }^{11}$.

Even though the two aspects are related, one can perceive a feeling of isolation while having strong social ties, and vice versa ${ }^{11}$. Out of the objective indicators of social isolation during the pandemic, the number of people in the household provided no significant correlations. This might be explained by the normal living situation of medical undergraduates. The majority of medical undergraduates study away from home, seeing their families and home at a frequency ranging from a few times every month to a few times a year. The only significant differences between students spending their lockdown with their family as opposed to away from them was an increase in anger which can be explained by the infringement of autonomy and intimacy that students experience with their families ${ }^{12}$. From this we can conclude that the major effects of isolation were not caused by the undergraduates' ability or inability to see their family, but much rather the physical separation from their other relationships.

This fact is corroborated by the differences in Loneliness and Interaction experienced by CoLocked and SoLocked undergraduates. This decrease in perceived loneliness by students who were living with their significant other is corroborated by literature ${ }^{13}$. One interesting finding is that SoLocked undergraduates reported no significant difference in Depression, Interactions and Loneliness when compared to their Single counterparts, but reported higher Frustration and Anger scores. This leads us to believe that the real determinant of perceived social isolation is not the existence of an intimate relationship, but much rather the possibility of frequent offline contact with one's significant other.

The markers of perceived social isolation (Loneliness, Friends and belief in the positive effect of a pet in the household) have been linked to a poorer response on our endpoints. These findings support the results found in the literature ${ }^{14-16}$. However, given the context in which the survey was realised, the causal relationship between stress and loneliness 5 is worth considering. Given the results we conclude that perceived social isolation is a more important determinant of mental health during a prolonged lockdown than actual physical isolation.

In the current literature there is a known correlation between social media usage and perceived social isolation, but the causal relationship between the two has not been clearly established ${ }^{6,13}$. Our findings suggest that social media usage isn't the cause of the increase in loneliness but much rather an effect of it. This hypothesis is supported by the existing literature ${ }^{13}$. However, given the disparity between people who have maintained their SMU habits and those who have either reduced or increased it, we propose that social media does not necessarily cause perceived social isolation, and in some cases might actually decrease the feeling of isolation one might face during a prolonged isolation period. This disparity between social media users is supported by the literature ${ }^{17}$. 


\section{Table 5. Friends Correlations}

\begin{tabular}{|l|l|l|l|l|l|}
\hline & R & R Square & P & B & Constant \\
\hline Loneliness & 0.299 & 0.090 & 0.0001 & -0.277 & 6.053 \\
\hline Depression & 0.323 & 0.104 & 0.0001 & -0.341 & 4.589 \\
\hline Purposelessness & 0.284 & 0.081 & 0.0001 & -0.296 & 4.190 \\
\hline Distractions & 0.335 & 0.112 & 0.0001 & 0.335 & 2.151 \\
\hline Energy & 0.399 & 0.159 & 0.0001 & 0.365 & 1.438 \\
\hline
\end{tabular}

According to our study, using social media more during lockdown had both positive and negative influence on the mental health of responders, but the negative aspects were dominant. The undergraduates who used social media more than before COVID-19 pandemic considered their mental stimulation less adequate, perceived a higher level of loneliness, frustration, anger, stress, sedentarism, sleep problems, time wasting, overeating, concentration problems, time management difficulties, and lower energy, self-determination and perception of having enough distracting activities. However, this category of students felt less depressed, more active and reported a lower level of purposelessness and they claimed to have enough people to discuss with during lockdown.

The relationship between streaming platforms usage and the endpoints follows the pattern of social media usage, the difference is that higher streaming platforms use is associated with lower activity and there was no statistically significant difference with Friends endpoint. Though the literature concerning SPU is rather lacking, we are proposing that the causal effect between time spent on streaming platforms and feelings of loneliness, concentration problems, overeating and sedentarism follow in part the same pattern as SMU, though the degree to which it influences the various endpoints differs. We believe that loneliness causes an initial increase in SMU and SPU, but consequently, as the use becomes more passive rather than active, the time spent in the on-line medium contributes to a worsening in mental health outcomes, creating a vicious cycle of loneliness and passive online escapism. The negative effect of passively using social media is supported by the existing literature ${ }^{6}$.

Our study also highlighted the importance of personality traits on the mental health of medical students during COVID-19 lockdown. Introverts were more satisfied with the level of interaction, while extroverts felt less depressed. Introverts also reported to have fewer activities to distract them and to perceive less self-determination. Extroverts claimed to feel more active and to have enough people to talk to during pandemic. Optimists reported having enough social interactions, feeling more mentally stimulated, less lonely, frustrated, angry, depressed, stressed, virophobic and sedentary. They also disagreed more with feeling purposelessness, having difficulties with time management, wasting time, overeating, having concentration and sleep problems. Optimists also felt more self-determined, more active and they claimed having enough people to discuss with and enough distracting activities. Except for Understanding, all endpoints were statistically associated with Optimism categories (optimist, pessimist, neither). Our findings suggest this personality trait has a high influence on the mental health of undergraduate students.

\section{CONCLUSIONS}

The mental health of medical students during COVID-19 lockdown is an important issue. It is influenced by various factors, such as personality traits (optimists), partner status, perceived social isolation, social media and streaming platforms usage. In order to increase the accuracy of the results, further studies should be conducted to evaluate the mental health by using more complex indicators for each endpoint and also objective methods to assess the status of the responders.

Compliance with ethics requirements: The authors declare no conflict of interest regarding this article. The authors declare that all the procedures and experiments of this study respect the ethical standards in the Helsinki Declaration of 1975, as revised in 2008(5), as well as the national law. Informed consent was obtained from all the patients included in the study.

Acknowledgements: Our thanks go to the Federation of Romanian Medical Students's Association for providing us with the platform for collecting the responses to our questionnaire. 


\section{References}

1. Kawano, S., \& Kakehashi, M. (2015). Substantial impact of school closure on the transmission dynamics during the pandemic Flu H1N1-2009 in Oita, Japan. PLoS ONE, 10(12), 1-15. https:// doi.org/10.1371/journal.pone.0144839

2. Al-Rabiaah, A., Temsah, M. H., Al-Eyadhy, A. A., Hasan, G. M., Al-Zamil, F., Al-Subaie, S., Alsohime, F., Jamal, A., Alhaboob, A., Al-Saadi, B., \& Somily, A. M. (2020). Middle East Respiratory Syndrome-Corona Virus (MERS-CoV) associated stress among medical students at a university teaching hospital in Saudi Arabia. Journal of Infection and Public Health, 13(5), 687-691. https://doi.org/10.1016/j.jiph.2020.01.005

3. Bhatti, A. B., \& Haq, A. ul. (2017). The Pathophysiology of Perceived Social Isolation: Effects on Health and Mortality. Cureus, 9(1), 1-10. https://doi.org/10.7759/cureus.994

4. Stuller, K. A., Jarrett, B., \& DeVries, A. C. (2012). Stress and social isolation increase vulnerability to stroke. Experimental Neurology, 233(1), 33-39. https://doi.org/10.1016/j.expneurol.2011.01.016

5. Campagne, D. M. (2019). Stress and perceived social isolation (loneliness). Archives of Gerontology and Geriatrics, 82(January), 192-199. https://doi.org/10.1016/j.archger.2019.02.007

6. Yang, C. C. (2016). Instagram Use, Loneliness, and Social Comparison Orientation: Interact and Browse on Social Media, but Don't Compare. Cyberpsychology, Behavior, and Social Networking, 19(12), 703-708. https://doi.org/10.1089/ cyber.2016.0201

7. Arrigo, B. A., \& Bullock, J. L. (2008). The psychological effects of solitary confinement on prisoners in supermax units: Reviewing what we know and recommending what should change. International Journal of Offender Therapy and Comparative Criminology, 52(6), 622-640. https://doi. org/10.1177/0306624X07309720

8. Belavý, D. L., Gast, U., Daumer, M., Fomina, E., Rawer, R., SchießI, H., Schneider, S., Schubert, H., Soaz, C., \& Felsenberg, D. (2013). Progressive Adaptation in Physical Activity and Neuromuscular Performance during 520d Confinement. PLoS ONE, 8(3), 1-7. https://doi.org/10.1371/journal.pone.0060090

9. Bartone, P. T., Krueger, G. P., \& Bartone, J. V. (2018). Individual differences in adaptability to isolated, confined, and extreme environments. Aerospace Medicine and Human Performance, 89(6), 536-546. https://doi.org/10.3357/AMHP.4951.2018

10. Gunderson, E. K. E. (1968). Mental Health Problems in Antarctica. Archives of Environmental Health, 17(4), 558-564. https:// doi.org/10.1080/00039896.1968.10665281

11. Holt-Lunstad, J., Smith, T. B., Baker, M., Harris, T., \& Stephenson, D. (2015). Loneliness and Social Isolation as Risk Factors for Mortality: A Meta-Analytic Review. Perspectives on Psychological Science, 10(2), 227-237. https://doi org/10.1177/1745691614568352

12. Laham, S. M., Chopra, S., Lalljee, M., \& Parkinson, B. (2010). Emotional and behavioural reactions to moral transgressions: Cross-cultural and individual variations in India and Britain International Journal of Psychology, 45(1), 64-71. https://doi. org/10.1080/00207590902913434

13. Primack, B. A., Shensa, A., Sidani, J. E., Whaite, E. O., Lin, L. yi, Rosen, D., Colditz, J. B., Radovic, A., \& Miller, E. (2017). Social Media Use and Perceived Social Isolation Among Young Adults in the U.S. American Journal of Preventive Medicine, 53(1), 1-8. https://doi.org/10.1016/j.amepre.2017.01.010

14. Dingemans, A., Danner, U., \& Parks, M. (2017). Emotion regulation in binge eating disorder: A review. Nutrients, 9(11), 1-11. https://doi.org/10.3390/nu9111274

15. Erzen, E., \& Çikrikci, Ö. (2018). The effect of loneliness on depression: A meta-analysis. International Journal of Social Psychiatry, 64(5), 427-435. https://doi.org/10.1177/0020764018776349

16. Jaremka, L. M., Peng, J., Bornstein, R., Alfano, C. M., Andridge, R. R., Povoski, S. P., Lipari, A. M., Agnese, D. M., Farrar, W. B., Yee, L. D., Carson, W. E., \& Kiecolt-Glaser, J. K. (2014). Cognitive problems among breast cancer survivors: Loneliness enhances risk. Psycho-Oncology, 23(12), 1356-1364. https://doi. org/10.1002/pon.3544

17. Pedrero-Pérez, E. J., Morales-Alonso, S., Rodríguez-Rives, E., Díaz-Olalla, J. M., Álvarez-Crespo, B., \& Benítez-Robredo, M. T. (2019). Smartphone nonusers: Associated sociodemographic and health variables. Cyberpsychology, Behavior, and Social Networking, 22(9), 597-603. https://doi.org/10.1089/ cyber.2019.0130

\section{APPENDICES AND FUNDING BODY}

\section{Appendix A - Questionnaire}

This appendix provides a detailed view of the questionnaire. In italics is the way in which we refer to the answers of a particular question throughout the article.

1. In which university centre do you study?

Dropbox with the 12 possible options in Romania

2. In which year are you now?

Dropbox from 1 to 6

3. How do you identify?

Male/ Female/ Prefer not to answer

4. In which environment do you spent your lockdown

Family home/ Personal home (or rent)/ Student dorm/ Other (open answer)

5. Do you spend the lockdown with your partner?

Yes/ No/ I do not have a partner 
6. How many people are in your household (yourself included)?

Open answer accepting only numbers

7. Do you have pets in your household?

Yes/ No

8. Do you believe that a pet would make your isolation experience more manageable?

Yes/ No

9. Where would you place yourself on the following scale? (Openness)

Sliding scale from 1 to 7 where 1 represents an Introvert and 7 an Extrovert

10. Where would you place yourself on the following scale? (Optimism)

Sliding scale from 1 to 7 where 1 represents a Pessimist and 7 an Optimist

11. How much have you been using Social Media since the lockdown started? (SMU) Just as much/ more than before/ less than before

12. How much have you been using Streaming Platforms (Netflix, HBO GO, YouTube, Disney+ etc) since the lockdown started? (SPU)

Just as much/ more than before/ less than before

\section{How much do you agree with the following statement?}

For these questions the answer was a sliding scale from 1 to 7 where 1 represented total disagreement and 7 total agreement.

13. I know the reason for social distancing (Understanding)

14. The amount of social interactions that I have are adequate (Interaction)

15. The mental stimulation I have is adequate (Stimulation)

16. I feel alone (Loneliness)

17. I feel frustrated (Frustration)

18. I feel angry (Anger)

19. I think I'm depressed (Depression)

20. I feel like I don't have a purpose anymore (Purposelessness)

21. I have difficulty organizing my time (TimeUnmanagement)

22. I spend a lot of my time with unproductive activities (TimeWasting)

23. I eat more than before (Overeating)

24. I have difficulty concentrating (ConcentrationProblems)

25. I feel stressed (Stress)

26. I am afraid I'll catch the virus (Virophobia)

27. I became more sedentary since the pandemic started (Sedentarism)

28. My sleep schedule was affected (SleepProblems)

29. I have enough activity to distract me from the way in which the pandemic affects my life (Distractions)

30. I feel full of energy (Energy)

31. I feel in control of my life (SelfDetermination)

32. I try to keep myself active (Activity)

33. I have enough people with whom to discuss (Friends) 